\title{
Anti-Allergic Properties of Propolis: Evidence From Preclinical and Clinical Studies
}

\author{
Kong Yen Liew ${ }^{1 \dagger}$, Nurain Irdayani Kamise ${ }^{1 \dagger}$, Hui Ming Ong ${ }^{1}$, Poi Yi Aw Yong ${ }^{2}$, \\ Fahmida Islam ${ }^{2}$, Ji Wei Tan ${ }^{2}$ and Chau Ling Tham ${ }^{1 *}$ \\ ${ }^{1}$ Department of Biomedical Sciences, Faculty of Medicine and Health Sciences, Universiti Putra Malaysia, Serdang, Malaysia, \\ ${ }^{2}$ School of Science, Monash University Malaysia, Subang Jaya, Malaysia
}

\section{OPEN ACCESS}

Edited by:

Jose Mauricio Sforcin,

São Paulo State University, Brazil

Reviewed by:

Maria Terezinha Peracoli, São Paulo State University, Brazil Wander Pavanelli, State University of Londrina, Brazil

*Correspondence:

Chau Ling Tham

chauling@upm.edu.my

${ }^{\dagger}$ These authors have contributed equally to this work and share first

authorship

Specialty section:

This article was submitted to Ethnopharmacology,

a section of the journal

Frontiers in Pharmacology

Received: 29 September 2021

Accepted: 22 December 2021

Published: 21 January 2022

Citation:

Liew KY, Kamise NI, Ong HM Aw Yong PY, Islam F, Tan JW and

Tham CL (2022) Anti-Allergic Properties of Propolis: Evidence From

Preclinical and Clinical Studies.

Front. Pharmacol. 12:785371.

doi: 10.3389/fphar.2021.785371
Allergic diseases are a global health burden with increasing prevalence. Side effects of available medications (antihistamines and steroids), lack of patients' perceived effectiveness and high cost of biologic therapies (omalizumab) are challenges to the clinical management of allergic diseases. As allergy symptoms persist for a long time, complementary and alternative medicine (CAM) such as propolis may be considered a potential prophylactic or therapeutic option to avoid long-term medication use. Propolis is a natural resinous substance produced by bees. Although propolis is well known to possess antioxidant, antimicrobial, and anticancer properties, its anti-allergic potential is not fully explored. Several preclinical studies demonstrated the therapeutic effects of propolis extracts against allergic inflammation, asthma, allergic rhinitis, atopic dermatitis, and food allergy, which may be partly attributed to their inhibitory effects on the activation of mast cells and basophils. Clinically, the consumption of propolis as a supplement or an adjunct therapy is safe and attenuates various pathological conditions in asthma. Such an approach may be adopted for atopic dermatitis and allergic rhinitis. Although flavonoids (chrysin, kaempferol, galangin, and pinocembrin) and cinnamic acid derivatives (artepillin $\mathrm{C}$ and caffeic acid phenethyl ester) can contribute to the anti-allergic activities, they may not be present in all propolis samples due to variations in the chemical composition. Future studies should relate the anti-allergic activity of propolis with its chemical contents. This mini-review summarizes and discusses existing preclinical and clinical studies reporting the anti-allergic activities of propolis to provide insights into its potential applications in allergic diseases.

Keywords: propolis, allergy, asthma, allergic rhinitis, atopic dermatitis, eczema, mast cell, basophil

\section{INTRODUCTION}

Allergic diseases are a global health problem affecting approximately $20-30 \%$ of the population in industrialized countries (Akdis, 2014). The prevalence of allergic diseases, such as allergic asthma, allergic rhinitis, atopic dermatitis, anaphylaxis, and food and drug allergies, is increasing worldwide, especially in low- and middle-income countries (Pawankar, 2014). Allergic diseases are complex and cause a broad spectrum of symptoms ranging from mild to severe and potentially life-threatening anaphylactic reactions (Kun and Li, 2016). 


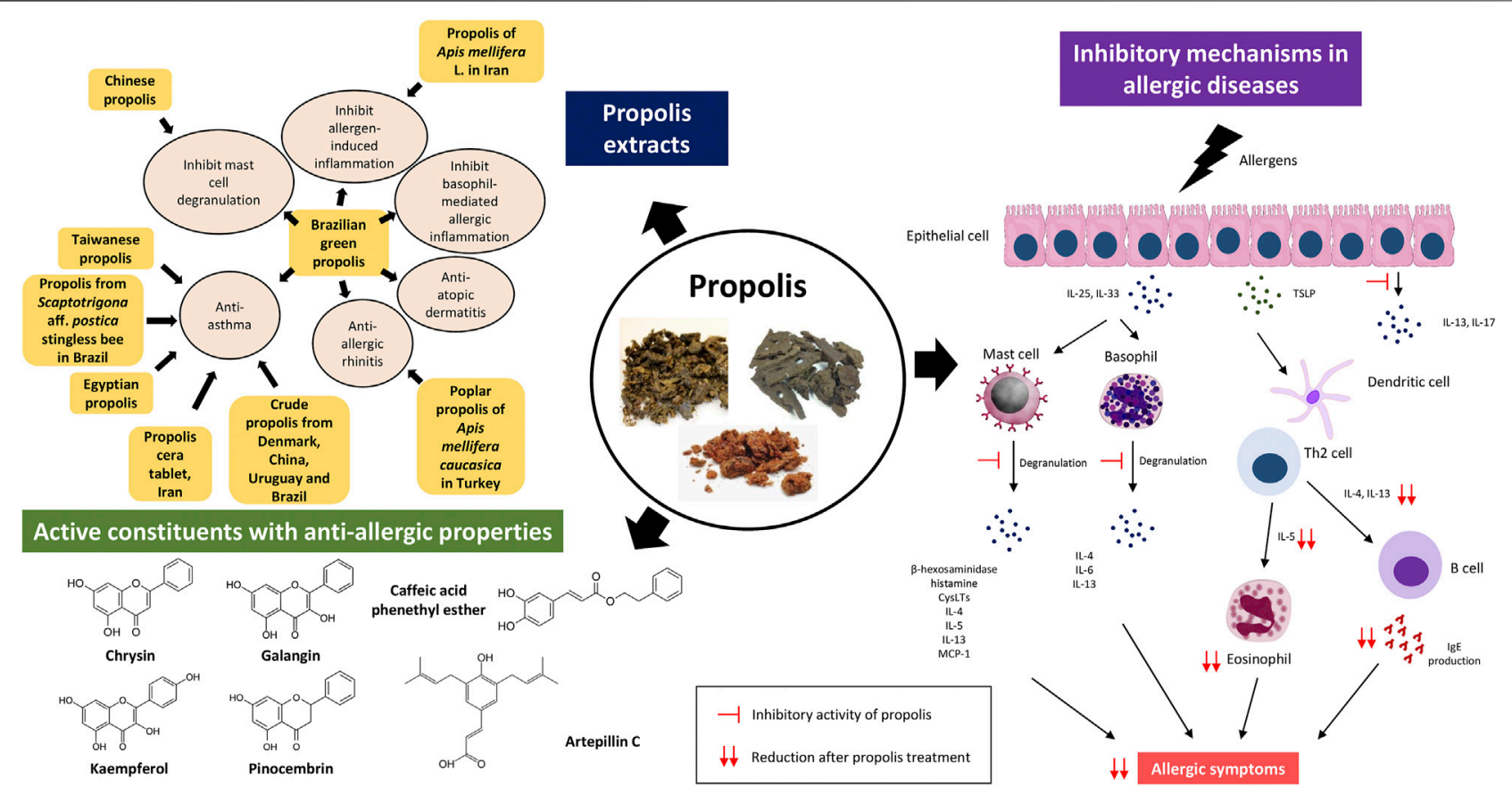

FIGURE 1 | Different types of propolis extracts have shown anti-allergic effects against allergic inflammation, asthma, allergic rhinitis, and atopic dermatitis. Brazilian green propolis is the most promising remedy for allergic diseases as it has been demonstrated to inhibit several pathophysiological mechanisms in allergy. The antiallergic properties of propolis may be partly attributed to the inhibitory activity of propolis on the activation of epithelial cells, mast cells, basophils, and eosinophils and the release of various allergic mediators. The active constituents of propolis with anti-allergic properties are flavonoids such as chrysin, kaempferol, galangin, and pinocembrin and cinnamic acid derivatives such as caffeic acid phenethyl esther (CAPE) and artepillin C. However, it should be noted that the chemical composition of propolis varies according to geographical locations, climates, botanical sources, and bee species. IL: Interleukin; TSLP: thymic stromal lymphopoietin; Th2: T helper 2; IgE: Immunoglobulin E; CysLTs: cysteinyl leukotrienes; MCP-1: monocyte chemoattractant protein-1.

In allergic diseases, mast cells, basophils, and eosinophils are the principal effector cells that regulate allergic inflammation. The binding of allergen to immunoglobulin $\mathrm{E}$ ( $\mathrm{IgE}$ ) causes cross-linking of IgE receptors such as FceRI and activates mast cells and basophils. This results in their degranulation and release of inflammatory mediators such as histamine, $\beta$-hexosaminidase, prostaglandins (PGs), cysteinyl leukotrienes (CysLTs), as well as pro-inflammatory cytokines and chemokines such as interleukin (IL)-4, IL-6, IL-8, IL-13, and tumour necrosis factor (TNF)- $\alpha$ (Stone et al., 2010). These mediators can cause rashes and itchy skin, sneezing, bronchoconstriction, and eosinophilic inflammation (Stone et al., 2010). Although antihistamines (loratadine and cetirizine) and anti-inflammatory drugs (inhaled and topical steroids) remain the mainstay of treatment for allergic diseases (Kruse and Vanijcharoenkarn, 2018), side effects such as nasal irritation and epistaxis, lack of patients' perceived effectiveness and high cost of biologic therapies targeting $\operatorname{IgE}$ (omalizumab) are challenges to the clinical management of allergic diseases (Kruse and Vanijcharoenkarn, 2018; Baiardini et al., 2019). Since allergy symptoms can persist for a long time and severely impact the patients' quality of life, complementary and alternative medicine (CAM) like propolis may be considered one of the prophylactic or therapeutic options for allergic diseases to avoid long-term medication use.

Propolis, also known as "bee glue," is a natural resinous substance produced by bees to protect their hives and combat infections. It is rich in flavonoids, terpenoids, phenolics and their esters, with more than 500 chemical compounds identified in propolis (Huang et al., 2014). Propolis has been traditionally used to treat burns, ulcers, asthma, and diabetes (Kuropatnicki et al., 2013). Besides that, propolis has been demonstrated to exhibit excellent anti-inflammatory, antimicrobial, and anticancer properties, and these have been extensively reviewed (Pasupuleti et al., 2017; Anjum et al., 2019; Zulhendri et al., 2021). However, there are not many studies investigating the antiallergic properties of propolis. Thus, the objective of this minireview is to summarize and critically discuss existing studies reporting the anti-allergic activities of propolis in both preclinical and clinical studies to provide insights into its potential applications in allergic diseases.

\section{PRECLINICAL STUDIES ON THE EFFECTS OF PROPOLIS IN VARIOUS CELLULAR AND ANIMAL MODELS OF ALLERGIC DISEASES}

\section{Allergen-Induced Allergic Inflammation}

An in vitro study by Khosravi et al. (2018) evaluated the effects of the ethanol extract of propolis collected from the hives of Apis mellifera L. bees of southern Iran on cytokine production in murine lung epithelial cells TC-1 JHU-1 induced with a fungal 
TABLE 1 | (A) Preclinical studies investigating the effects of propolis in different cellular and animal models of allergic diseases. (B) Clinical studies investigating the effects of propolis in different allergic diseases.

$\begin{array}{lllll}\text { Type of allergic } & \text { Type of propolis } & \text { Experimental model; inducer } & \text { Treatment } & \text { Mode of treatment; }\end{array}$
disease

\section{Experimental model; inducer}

Alergen-induced

Allergen-induced propolis ethanol extract

(Iran)

Brazilian green propolis ethanol extract
Water extract (WEP) and

Mast cell

degranulation Water extract (WEP) and
ethanol extract (EEP)
of propolis from China and Brazil

Brazilian green propolis

ethanol extract

Brazilian green propolis

powder

Propolis hydroalcoholic extract produced by Scaptotrigona aff.

In vitro (murine lung epithelial cells TC- $1 \mathrm{JHU}-25 \mu \mathrm{g} / \mathrm{ml}$

1); Aspergillus fumigatus conidia

Ex vivo (peripheral leukocytes and peripheral 3, 10, 30 and blood mononuclear cells from 10 allergic

$100 \mu \mathrm{g} / \mathrm{ml}$ patients); Cry j
In vitro (RBL-2H3): Anti-DNP IgE sensitization followed by DNP-BSA challenge

$0.01,0.1$ and $1 \%$ (WEP and EEP)

Ex vivo (rat peritoneal mast cells); antigen or compound $48 / 80$

$3,10,30$ and

$100 \mu \mathrm{g} / \mathrm{ml}$
In vivo (BALB/c mice); Anti-DNP IgE

sensitization followed by intradermal $\mathrm{DNP}_{11}$ OVA challenge

In vivo (BALB/c mice); OVA

$0.3 \mathrm{mg}$ asthmatic mice); concanavalin A or OVA

In vivo (2-3 months old female BALB/C mice); OVA
Co-treatment (6 or 12 h); NA

Co-treatment (6 days); NA

$\begin{aligned} & \text { leukocytes } \\ & \downarrow \text { cysLTs }\end{aligned}$

$\downarrow$ cysLTs
$\downarrow$ histamine

In Cry j1-induced peripheral

blood mononuclear cells

$\downarrow$ IL-5 and IL-13

\section{WEP and EEP from China and} Brazil

$\downarrow \beta$-hexosaminidase release

Pre-treatment $(30 \mathrm{~min}, 3 \mathrm{~h}$ or

18 h); NA

Pre-treatment (10 min); NA

$\downarrow$ histamine release

Shinmei et al. (2004),

Shinmei et al. (2009),

Shinmei et al. (2010)

Treatment on each of 3 alternate days before anti-DNP IgE sensitization; Intragastric

ear skin thickness

$\downarrow$ inflammation and leukocytes

infiltration in ears

$\downarrow$ Mcpt8 gene expression in ear

tissues

Twice a week for 3 weeks from day $\quad \downarrow$ diarrhoea occurrence 28; Oral

$\downarrow$ clinical scores

$\downarrow$ serum $\mathrm{mMCP}-1$

$\downarrow$ LL-4 and E-NPP3 gene

expression in jejuna

Ex vivo (bone marrow-derived basophils from $\quad 1,10$ and $100 \mu \mathrm{g} / \mathrm{ml} \quad$ Pre-treatment $(6 \mathrm{~h})$ or co-treatment $\quad \downarrow$ phosphorylation of FceR

BALB/c mice); Anti-DNP IgE sensitization

followed by $\mathrm{DNP}_{23}-\mathrm{HSA}$ challenge

(24 h); NA

signalling molecules (Lyn,

Akt and Erk)

$\downarrow$ IL-4, IL-6 and IL-13 production

65 and $325 \mathrm{mg} / \mathrm{kg} \quad \begin{aligned} & \text { Daily for up to } 9 \text { weeks after second } \\ & \text { OVA sensitization; Oral }\end{aligned}$

$g G_{1}$

$\uparrow$ serum OVA-specific $\lg G_{2 a}$

$\downarrow$ airway hyperresponsiveness

$\downarrow$ LL-5 in BALF

$\downarrow$ lung inflammation

In ConA-induced splenocytes

$\uparrow$ IFN- $\gamma$

In OVA-induced splenocytes

$\downarrow$ IL-6, IL-10 and IFN- $\gamma$

$\begin{array}{ll}\text { Daily for } 2 \text { weeks after second OVA } & \downarrow \text { total cell counts and } \\ \text { sensitization; Oral } & \text { polymorphonuclear cells in }\end{array}$

BALF
Kashiwakura et al. (2021) Sy et al. (2006)

Farias et al. (2014)

(Continued on following page) 
TABLE 1 | (Continued) (A) Preclinical studies investigating the effects of propolis in different cellular and animal models of allergic diseases. (B) Clinical studies investigating the effects of propolis in different allergic diseases.

\begin{tabular}{|c|c|c|c|c|c|c|}
\hline $\begin{array}{l}\text { Type of allergic } \\
\text { disease }\end{array}$ & Type of propolis & Experimental model; inducer & $\begin{array}{l}\text { Treatment } \\
\text { concentration/ } \\
\text { dose }\end{array}$ & $\begin{array}{l}\text { Mode of treatment; } \\
\text { route of administration }\end{array}$ & Experimental outcome & References \\
\hline & $\begin{array}{l}\text { postica stingless bee } \\
\text { (Brazil) }\end{array}$ & & & & $\begin{array}{l}\downarrow \text { peribronchovascular } \\
\text { inflammation and } \\
\text { epithelial desquamation } \\
\downarrow \text { serum IFN- } \gamma\end{array}$ & \\
\hline & $\begin{array}{l}\text { Propolis aqueous and } \\
\text { ethanol crude } \\
\text { extract (Egypt) }\end{array}$ & $\begin{array}{l}\text { In vivo (6 weeks old male albino CD1 mice); } \\
\text { conalbumin }\end{array}$ & $30 \mathrm{mg} / \mathrm{kg}$ & $\begin{array}{l}\text { Daily for } 18 \text { days after second } \\
\text { conalbumin sensitization; } \\
\text { Intraperitoneal }\end{array}$ & $\begin{array}{l}\downarrow \text { blood eosinophils and } \\
\text { basophils } \\
\downarrow \text { lung inflammation } \\
\text { (peribronchial and perivascular } \\
\text { inflammatory cell) }\end{array}$ & El-Aidy et al. (2015) \\
\hline & $\begin{array}{l}\text { Standardized Brazilian } \\
\text { green propolis } \\
\text { extract (EPP-AF } \\
\text { extract) }\end{array}$ & $\begin{array}{l}\text { In vivo (6-8 weeks old female C57BL/6 } \\
\text { mice); OVA }\end{array}$ & $150 \mathrm{mg} / \mathrm{kg}$ & $\begin{array}{l}\text { Daily for } 17-22 \text { days after second } \\
\text { OVA sensitization; Oral }\end{array}$ & $\begin{array}{l}\downarrow \text { pulmonary inflammation } \\
\downarrow \text { mucus production } \\
\downarrow \text { IL-5 and eosinophils in BALF } \\
\downarrow \text { IL-13 gene expression in lungs } \\
\downarrow \text { eosinophils and M2 } \\
\text { macrophages in lungs } \\
\uparrow \text { PMN-MDSC and CD4 }{ }^{+} \\
\text {Foxp3+ regulatory T cells in } \\
\text { lungs }\end{array}$ & Piñeros et al. (2020) \\
\hline \multirow[t]{3}{*}{ Allergic rhinitis } & $\begin{array}{l}\text { Brazilian green propolis } \\
\text { granular }\end{array}$ & $\begin{array}{l}\text { In vivo ( } 5 \text { weeks old male BALB/c mice); OVA } \\
\text { or histamine }\end{array}$ & $\begin{array}{l}200,500 \text { and } \\
1,000 \mathrm{mg} / \mathrm{kg}\end{array}$ & Daily for 4 weeks; Oral & $\begin{array}{l}\text { Repeated administration of } \\
\text { propolis ( } 2-4 \text { weeks) } \\
\downarrow \text { sneezing and nasal rubbing }\end{array}$ & Shinmei et al. (2009) \\
\hline & $\begin{array}{l}\text { Propolis ethanol extract } \\
\text { (poplar propolis } \\
\text { collected from honeybee } \\
\text { colonies of Apis } \\
\text { mellifera caucasica, } \\
\text { Turkey) }\end{array}$ & $\begin{array}{l}\text { In vivo (male Sprague-Dawley rats aged } \geq 6 \\
\text { weeks); OVA }\end{array}$ & 200 mg/kg & $\begin{array}{l}\text { Daily for } 21 \text { days after last OVA } \\
\text { sensitization; Oral and intranasal }\end{array}$ & $\begin{array}{l}\text { Oral propolis } \\
\downarrow \text { ciliary loss, inflammation, } \\
\text { vascular proliferation, } \\
\text { increase in goblet cells and } \\
\text { eosinophils in the } \\
\text { nasal mucosa } \\
\downarrow \text { symptom scores (nasal } \\
\text { irritation, sneezing } \\
\text { and amount of nasal secretion) } \\
\text { on days } 1-4 \\
\text { Intranasal propolis } \\
\downarrow \text { vascular congestion, } \\
\text { eosinophils and } \\
\text { chondrocytes in the nasal } \\
\text { mucosa } \\
\downarrow \text { symptom scores (nasal } \\
\text { irritation, sneezing } \\
\text { and amount of nasal secretion) } \\
\text { on days } 1,3 \text { and } 4\end{array}$ & Yasar et al. (2016) \\
\hline & $\begin{array}{l}\text { Brazilian green propolis } \\
\text { ethanol extract }\end{array}$ & $\begin{array}{l}\text { In vivo ( } 6 \text { weeks old male Brown Norway rats); } \\
\text { toluene } 2,4 \text {-diisocyanate (TDI) }\end{array}$ & 40 and $80 \mathrm{mg} / \mathrm{kg}$ & $\begin{array}{l}\text { Daily for } 3 \text { weeks before TDI } \\
\text { sensitization; Oral }\end{array}$ & $\begin{array}{l}\downarrow \text { sneezing } \\
\downarrow \text { nasal scores (watery } \\
\text { rhinorrhea, swelling and } \\
\text { redness) } \\
\downarrow \text { H1R mRNA levels in the nasal } \\
\text { mucosa }\end{array}$ & Shaha et al. (2018) \\
\hline
\end{tabular}


TABLE 1 | (Continued) (A) Preclinical studies investigating the effects of propolis in different cellular and animal models of allergic diseases. (B) Clinical studies investigating the effects of propolis in different allergic diseases.

\begin{tabular}{|c|c|c|c|c|c|c|}
\hline $\begin{array}{l}\text { Type of allergic } \\
\text { disease }\end{array}$ & Type of propolis & Experimental model; inducer & $\begin{array}{l}\text { Treatment } \\
\text { concentration/ } \\
\text { dose }\end{array}$ & $\begin{array}{l}\text { Mode of treatment; } \\
\text { route of administration }\end{array}$ & Experimental outcome & References \\
\hline & & $\begin{array}{l}\text { In vitro (HeLa); histamine or phorbol-12- } \\
\text { myristate-13-acetate (PMA) } \\
\text { In vitro (RBL-2H3); ionomycin }\end{array}$ & $\begin{array}{l}25,50 \text { and } 75 \mu \mathrm{g} / \mathrm{ml} \\
25,75 \text { and } 100 \mu \mathrm{g} / \mathrm{ml}\end{array}$ & $\begin{array}{l}\text { Pre-treatment (3 h); NA } \\
\text { Pre-treatment (3 h); NA }\end{array}$ & $\begin{array}{l}\downarrow \text { IL-4, IL-5 and IL-9 mRNA } \\
\text { levels in the nasal mucosa } \\
\downarrow \text { H1R gene expression } \\
\downarrow \text { PKC } \delta \text { phosphorylation at } \\
\text { Tyr311 } \\
\downarrow \text { IL-9 gene expression }\end{array}$ & \\
\hline \multirow[t]{2}{*}{ Atopic dermatitis } & $\begin{array}{l}\text { Brazilian green propolis } \\
\text { granular }\end{array}$ & $\begin{array}{l}\text { In vivo (6-10 weeks old female ICR rats); } \\
\text { compound } 48 / 80 \text { or histamine (intradermal } \\
\text { injection) }\end{array}$ & $\begin{array}{l}200,500 \text { and } \\
1,000 \mathrm{mg} / \mathrm{kg}\end{array}$ & Daily for 4 weeks; Oral & $\begin{array}{l}\text { In rats induced with compound } \\
48 / 80 \\
\downarrow \text { scratching behaviour } \\
\downarrow \text { skin vascular permeability }\end{array}$ & Shinmei et al. (2004) \\
\hline & $\begin{array}{l}\text { Brazilian green propolis } \\
\text { ethanol extract }\end{array}$ & $\begin{array}{l}\text { In vivo (6-10 weeks old female ICR rats); } \\
\text { compound } 48 / 80 \text { or histamine }\end{array}$ & $0.3,1$ and $3 \mathrm{mg} / \mathrm{site}$ & $\begin{array}{l}\text { Applied } 60 \text { min before compound } \\
48 / 80 \text { or histamine injection; } \\
\text { Topical }\end{array}$ & $\begin{array}{l}\text { In rats induced with compound } \\
48 / 80 \\
\downarrow \text { scratching behaviour }(0,15,30 \\
\text { and } 60 \text { min) } \\
\downarrow \text { skin vascular permeability }\end{array}$ & Shinmei et al. (2010) \\
\hline
\end{tabular}

\begin{tabular}{|c|c|c|c|c|c|c|}
\hline $\begin{array}{l}\text { Type } \\
\text { of allergic } \\
\text { disease }\end{array}$ & Type of propolis & $\begin{array}{l}\text { Subjects (age, gender } \\
\text { and number) }\end{array}$ & $\begin{array}{l}\text { Treatment method and } \\
\text { frequency }\end{array}$ & Experimental outcome & $\begin{array}{c}\text { Anti-allergic } \\
\text { properties } \\
(\mathrm{Y} / \mathrm{N})\end{array}$ & References \\
\hline \multirow[t]{2}{*}{ Asthma } & $\begin{array}{l}\text { Propolis aqueous extract (Propharma, } \\
\text { Stenlose, Denmark) prepared from crude } \\
\text { propolis collected from Denmark, China, } \\
\text { Uruguay and Brazil }\end{array}$ & $\begin{array}{l}\text { Individuals with mild to moderate } \\
\text { asthma for the last } 2-5 \text { years } \\
\text { 19-52 years; } 36 \text { male, } 10 \text { female } \\
\text { Propolis }(n=24) \\
\text { Placebo }(n=22)\end{array}$ & $\begin{array}{l}\text { Propolis group: oral theophylline + } \\
\text { propolis-containing sachet } \\
\text { Placebo group: oral theophylline + } \\
\text { placebo-containing sachet } \\
\text { Once daily for } 2 \text { months } \\
\text { Propolis group: } 3 \text { propolis tablets/day } \\
\text { (75 mg propolis) }\end{array}$ & $\begin{array}{l}\downarrow \text { nocturnal attacks } \\
\uparrow \text { pulmonary ventilatory functions (FVC, FEV1, } \\
\text { PEFR, FEF25-75) } \\
\downarrow \text { serum TNF- } \alpha, \text { IL-6, IL-10 and ICAM-1 } \\
\uparrow \text { serum IL-10 } \\
\downarrow \text { serum PGE } 2, \text { PGF }_{2 a} \text { and } \mathrm{LTD}_{4} \\
\downarrow \text { cough, dyspnea, wheezing and nocturnal }\end{array}$ & Y & $\begin{array}{l}\text { Khayyal et al. } \\
\text { (2003) }\end{array}$ \\
\hline & $\begin{array}{l}\text { Propolis cera tablet (Soren Tech Toos } \\
\text { Company, Mashhad, Iran) }\end{array}$ & $\begin{array}{l}\text { Individuals with newly diagnosed, } \\
\text { previously untreated moderate } \\
\text { asthma } \\
44.6 \pm 18.5 \text { years; } 32 \text { male, } 20 \\
\text { female } \\
\text { Propolis }(n=26) \\
\text { Placebo }(n=26)\end{array}$ & $\begin{array}{l}\text { Placebo group: } 3 \text { placebo } \\
\text { tablets/day } \\
\text { Daily for } 1 \text { month }\end{array}$ & $\begin{array}{l}\text { symptoms } \\
\downarrow \text { airway hyperresponsiveness } \\
\uparrow \text { Asthma Control Test scores } \\
\uparrow \text { FEV1, FEV1/FVC, PEFR, FEF25-75 } \\
\downarrow \text { FeNO } \\
\downarrow \text { sputum eosinophils }\end{array}$ & Y & $\begin{array}{l}\text { Mirsadraee } \\
\text { et al. (2020) }\end{array}$ \\
\hline $\begin{array}{l}\text { Atopic } \\
\text { sensitization and } \\
\text { eczema }\end{array}$ & $\begin{array}{l}\text { Brazilian green propolis extract (Yamada } \\
\text { Bee Farm Co., Ltd., Okayama, Japan) }\end{array}$ & $\begin{array}{l}\text { Lactating women (>20 years old) } \\
\text { having atopic symptoms and their } \\
\text { offspring ( } 2-8 \text { months) having eczema } \\
\text { Propolis }(n=40) \\
\text { Placebo }(n=40)\end{array}$ & $\begin{array}{l}\text { Propolis group: } 3 \text { propolis capsules/ } \\
\text { day (100 mg propolis extract/ } \\
\text { capsule) } \\
\text { Placebo group: } 3 \text { placebo capsules/ } \\
\text { day (propolis replaced with safflower } \\
\text { oil) } \\
\text { From the day of enrollment when their } \\
\text { offspring were between } 2 \text { and } \\
8 \text { months of age until their first } \\
\text { birthday }\end{array}$ & $\begin{array}{l}\leftrightarrow \text { atopic sensitization (serum levels of total lgE and } \\
\text { antigen-specific lgE for mites, egg white, cow's } \\
\text { milk, and wheat) at the first birthday of offspring } \\
\leftrightarrow \text { non-specific symptoms (eczema) in mothers } \\
\text { and their offspring }\end{array}$ & $\mathrm{N}$ & $\begin{array}{l}\text { lgarashi et al. } \\
(2019)\end{array}$ \\
\hline
\end{tabular}


allergen, Aspergillus fumigatus conidia (Khosravi et al., 2018) (Table 1A). Propolis ethanol extract treatment has been shown to suppress the production of IL-13 and IL-17 pro-inflammatory cytokines and increase IL-12 production. A. fumigatus can cause allergic inflammation in people suffering from allergic bronchopulmonary aspergillosis (ABPA), allergic Aspergillus sinusitis, and asthma. Thus, these findings suggest the potential therapeutic effect of propolis for allergic disorders.

Another study conducted by Tani et al. (2010) investigated the anti-allergic effects of Brazilian green propolis ethanol extract using peripheral leukocytes and peripheral blood mononuclear cells (PBMCs) isolated from patients who had a clinical history of pollinosis and were sensitized to Japanese cedar pollen, Cry j1/2 (Tani et al., 2010). Brazilian green propolis ethanol extract concentration-dependently inhibited CysLTs release in Cry j1induced peripheral leukocytes with an $\mathrm{IC}_{50}$ value of $5.8 \mu \mathrm{g} / \mathrm{ml}$. On the other hand, a significant inhibitory effect on histamine release was only observed at a high concentration of ethanol extract at $100 \mu \mathrm{g} / \mathrm{ml}$. This implies that the bioactive compound(s) that inhibited histamine release may be present in a low quantity in the extract. In Cry j1-induced PBMCs, the propolis ethanol extract also non-significantly inhibited IL-5 and IL-13 production. As the Brazilian green propolis contains relatively higher amounts of artepillin C (20.7\%), bacharrin (7.5\%) and kaempferide (3.6\%), these active constituents were believed to contribute to the inhibitory effect of the extract on CysLTs release. However, as suggested by the authors, it is crucial to determine whether the low abundance compound(s) will exert a more substantial effect than the high-abundance compounds.

Collectively, propolis has been shown to exert inhibitory effects against allergic inflammatory responses in different cellular models, including epithelial cells and immune cells such as peripheral leukocytes and PBMCs (Tani et al., 2010; Khosravi et al., 2018).

\section{Mast Cell Degranulation}

Nakamura et al. (2010) conducted a study to compare the effects of water (WEP) and ethanol (EEP) extracts of propolis originated from China and Brazil on mast cell degranulation using a rat basophilic leukaemia cell line, RBL-2H3 (Nakamura et al., 2010). Anti-dinitrophenyl (DNP)-IgE sensitized-RBL-2H3 cells are commonly induced with DNP-bovine serum albumin (BSA) to simulate the mast cell degranulation process. It has been shown that WEP and EEP from China exerted more substantial inhibitory effects on $\beta$-hexosaminidase release in activated RBL-2H3 cells compared with WEP and EEP from Brazil. Regardless of the origin, EEP was reported to be more potent than WEP in suppressing mast cell degranulation, suggesting that the ethanol extract of propolis may contain more active constituents with anti-allergic properties than the water extract. Further analysis of China's EEP revealed that chrysin and kaempferol are the primary active constituents contributing to the Chinese propolis' anti-allergic activity. By contrast, chrysin and kaempferol were below detectable levels in Brazilian propolis, possibly explaining why Brazilian propolis showed weaker inhibitory effects on mast cell degranulation than Chinese propolis. Consistent with the finding reported by Nakamura et al. (2010), a few other studies by the same group of researchers (Shinmei et al., 2004, 2009, 2010) have also demonstrated the inhibitory effects of Brazilian green propolis ethanol extract on histamine release in rat peritoneal mast cells induced with compound 48/80, a commonly used mast cell activator. The results of propolis in allergic diseases such as asthma, allergic rhinitis and atopic dermatitis in which mast cell degranulation plays a crucial role are further discussed in subsequent sections.

\section{Basophil-Mediated Allergic Inflammation}

Other than mast cells, propolis has also been shown to modulate the cellular responses of basophils. In a study by Kashiwakura et al. (2021), bone marrow-derived basophils (BMBs) induced with $\mathrm{DNP}_{23}$-human serum albumin (HSA) and treated with propolis at a concentration of $100 \mu \mathrm{g} / \mathrm{ml}$ showed a significantly reduced production of pro-inflammatory cytokines, IL-4, IL-6 and IL-13, by inhibiting the phosphorylation of Lyn, protein kinase B (Akt) and extracellular signal-regulated kinase (Erk) (Kashiwakura et al., 2021). Consistent with the in vitro finding, Kashiwakura et al. (2021) demonstrated that propolis treatment suppressed basophil-mediated skin and allergic intestinal inflammation in vivo using ovalbumin (OVA)-induced mouse models of chronic allergic inflammation (CAI) and food allergy, respectively. In the mouse model of CAI, propolis $(0.3 \mathrm{mg})$ administered intragastrically reduced skin thickness and inflammation of ears. In mice with food allergy, oral propolis treatment $(0.3 \mathrm{mg})$ also reduced diarrhoea occurrence, clinical scores, and serum levels of mouse mast cell protease-1 (mMCP1). The gene expression of IL-4 and ectonucleotide pyrophosphatase/phosphodiesterase family member 3 (ENPP3 ), a marker of activated basophil, in the jejuna was also reduced, suggesting that propolis treatment also inhibited basophil activation in vivo.

\section{Asthma}

An in vivo study by Sy et al. (2006) evaluated the potential therapeutic effects of Taiwanese propolis water extract for asthma using OVA-induced asthmatic mice (Sy et al., 2006). Administration of propolis treatment ( 65 and $325 \mathrm{mg} / \mathrm{kg}$ ) via tube feeding attenuated airway hyperresponsiveness and lung inflammation and reduced IL-5 levels in bronchoalveolar lavage fluid (BALF). However, the low dose $(65 \mathrm{mg} / \mathrm{kg})$ and high dose $(325 \mathrm{mg} / \mathrm{kg})$ propolis treatment had a distinct effect on the levels of OVA-specific IgE and $\operatorname{IgG}_{1}$ (Th2 response) and OVA-specific $\mathrm{IgG}_{2 \alpha}$ (Th1 response), where the low dose treatment decreased OVA-specific IgE and $\operatorname{IgG}_{1}$ with no effect on $\operatorname{IgG}_{2 \alpha}$. By contrast, the high dose treatment increased OVA-specific $\operatorname{IgG}_{2 \alpha}$ with no impact on OVA-specific IgE and $\operatorname{IgG}_{1}$. This indicates that the active constituents of the Taiwanese propolis water extract may consist of both Th1 and Th2 response regulators; however, further study is required to confirm that. Overall, Taiwanese propolis water extract may benefit asthma due to its modulatory effect on Th1 and Th2 responses.

Using a murine model of OVA-induced asthma, De Farias et al. (2014) demonstrated that propolis hydroalcoholic extract (PHE) reduced polymorphonuclear cell and total cell counts in 
BALF, peribronchovascular inflammation and epithelial desquamation in lungs as well as IFN- $\gamma$ levels in serum, indicating that the propolis produced by Scaptotrigona aff. postica stingless bee in Brazil may have potential therapeutic effects for asthma by suppressing pulmonary inflammation (De Farias et al., 2014). Notably, when administered orally at 50 and $200 \mathrm{mg} / \mathrm{kg}$ to OVA-induced asthmatic mice, the PHE results were comparable to that of $1 \mathrm{mg} / \mathrm{kg}$ of intraperitoneal dexamethasone treatment. The authors claimed that propolis treatment might be safer than dexamethasone because immunosuppression was only observed on the mice receiving dexamethasone, but not propolis treatment.

Besides that, El-Aidy et al. (2015) conducted a study to investigate the anti-asthmatic effects of a few bee products, including propolis, honey, and royal jelly (El-Aidy et al., 2015). They demonstrated that propolis ethanol extract and water extract at a dose of $30 \mathrm{mg} / \mathrm{kg}$ reduced eosinophils and basophils in the blood and inflammatory cells in the peribronchial and perivascular regions in the lungs of conalbumin-induced asthmatic mice. However, assessments on the other pathological changes in asthma such as airway hyperresponsiveness, serum IgE levels, and Th1/Th2 cytokines were not carried out. Nonetheless, a comparison of both extracts' chemical compositions may lead to identifying new anti-allergic compound(s).

A study by Piñeros et al. (2020) reported that a standardized Brazilian green propolis extract $\left(\mathrm{EPP}-\mathrm{AF}^{\circledR}\right)$ was able to inhibit pulmonary inflammation and mucus production as well as to reduce IL-5 and eosinophils in BALF in OVA-induced asthmatic mice (Piñeros et al., 2020). EPP-AF ${ }^{\circledR}(150 \mathrm{mg} / \mathrm{kg})$ administered via oral route was shown to increase the numbers of polymorphonuclear-myeloid derived suppressor cells (PMNMDSC) and $\mathrm{CD}^{+}$Foxp3+ regulatory $\mathrm{T}$ cells, which have been shown to regulate Th2 responses in the lungs negatively. Therefore, the anti-asthmatic effects of EPP-AF ${ }^{\circledR}$ were likely related to its immunoregulatory activities.

\section{Allergic Rhinitis}

An in vivo study by Shinmei et al. (2009) investigated the effects of Brazilian propolis granular obtained from Yamada Apiculture Center Inc., Okayama, Japan, on allergic rhinitis symptoms such as sneezing and nasal rubbing over 4 weeks (Shinmei et al., 2009). The study demonstrated that a single administration of propolis treatment $(200,500$ and $1,000 \mathrm{mg} / \mathrm{kg})$ via oral route had no effect on sneezing and nasal rubbing in OVA-sensitized mice induced with antigen. However, repeated administration of propolis resulted in a gradual improvement of symptoms in mice receiving $1,000 \mathrm{mg} / \mathrm{kg}$ of propolis treatment, where sneezing and nasal rubbing were significantly reduced from week two until week four. The effects of propolis were similar to a mast cell stabilizer, Tranilast, which also gradually reduced sneezing and nasal rubbing with significant inhibition observed in mice receiving oral treatment of Tranilast $(300 \mathrm{mg} / \mathrm{kg})$ starting from week three onwards. Neither single nor repeated administration of propolis treatment reduced serum IgE levels, suggesting that propolis has no inhibitory effect on IgE production. Propolis treatment also did not affect allergic rhinitis symptoms in non- sensitized mice induced with histamine, indicating that propolis did not block the action of histamine. On the other hand, Brazilian green propolis ethanol extract produced from the Brazilian propolis granular suppressed histamine release in mast cells induced with antigen or compound 48/80. Therefore, the beneficial effects of propolis on allergic rhinitis symptoms are likely to be due to the inhibition of histamine release by activated mast cells rather than blocking the activity of histamine.

Yasar et al. (2016) conducted a study to investigate the effects of poplar propolis produced by Apis mellifera caucasica honeybees in Turkey on allergic rhinitis (Yasar et al., 2016). The authors compared the anti-allergic activity of propolis ethanol extract administered via two different routes, which were oral and intranasal. The results showed that oral propolis was more effective than intranasal propolis in reducing inflammation, vascular proliferation, increase in goblet cells, and symptom scores (nasal irritation, sneezing, and amount of nasal secretion). Notably, the inhibitory effects of oral propolis at $200 \mathrm{mg} / \mathrm{kg}$ on inflammation and goblet cell counts in nasal mucosa as well as symptoms scores were more substantial than $50 \mu \mathrm{g}$ intranasal mometasone furoate (a steroidal drug) and $10 \mathrm{mg} / \mathrm{kg}$ oral ketotifen (an antihistamine), suggesting the potential use of poplar propolis produced by Apis mellifera caucasica honeybees as an oral treatment for allergic rhinitis.

Another study by Shaha et al. (2018) evaluated the potential therapeutic effects of Brazilian green propolis ethanol extract in rats with 2, 4-diisocyanate (TDI)-induced allergic rhinitis (Shaha et al., 2018). In rats receiving Brazilian green propolis ethanol extract treatment (40 and $80 \mathrm{mg} / \mathrm{kg}$ ) orally, sneezing, water rhinorrhea, swelling, and redness of nasal mucosa were attenuated. Gene expression levels of histamine $\mathrm{H} 1$ receptor (H1R) and pro-inflammatory cytokines such as IL-4, IL-5, and IL-9 in the nasal mucosa of TDI-induced rats receiving propolis treatment were also inhibited. This suggests that Brazilian green propolis could suppress inflammatory responses in the nasal mucosa other than providing symptomatic relief.

\section{Atopic Dermatitis}

Brazilian green propolis has been shown to ameliorate itching in animal models of atopic dermatitis when administered orally (Shinmei et al., 2004) or applied topically (Shinmei et al., 2010). A study by Shinmei et al. (2004) assessed the effects of Brazilian green propolis granular on atopic dermatitis in rats induced with compound $48 / 80$ or histamine. A single administration of propolis to the compound $48 / 80$-induced rats via oral route at a dose of $1,000 \mathrm{mg} / \mathrm{kg}$ significantly suppressed scratching frequency and reduced skin vascular permeability. The inhibitory effects of propolis increased gradually when the treatment was continued daily for 4 weeks. Similar therapeutic effects of Brazilian green propolis for atopic dermatitis were demonstrated by another study by Shinmei et al. (2010), which assessed the efficacy of topical propolis to relieve itch in compound 48/80-induced rats. Interestingly, Brazilian green propolis ethanol extract applied at a dose of $3 \mathrm{mg}$ per site on skin 60 min before the inducer compound 48/80 was injected intradermally suppressed scratching behaviours. The effect was 
prolonged until $60 \mathrm{~min}$. The authors suggest that the prolonged effect of propolis against scratching might be due to its inhibition of the mast-cell dependent late-phase reaction. In contrast to oral propolis, which required an extremely high dose $(1,000 \mathrm{mg} / \mathrm{kg})$ to relieve itching, topical propolis was effective at a lower dose ( $3 \mathrm{mg} / \mathrm{site}$ ). This suggests that topical propolis may be a more potent treatment for atopic dermatitis compared to oral propolis.

\section{CLINICAL STUDIES ON THE EFFECTS OF PROPOLIS IN ALLERGIC DISEASES}

\section{Asthma}

A comparative placebo-controlled clinical study by Khayyal et al. (2003) investigated the potential beneficial effects of a milk formula containing propolis aqueous extract as an adjuvant therapy for asthma (Khayyal et al., 2003) (Table 1B). In addition to oral theophylline as a regular medication, subjects with mild to moderate asthma drank milk prepared from propolis sachet or placebo sachet daily for 2 months. Significant reductions in the frequency and severity of nocturnal attacks and improvements in pulmonary ventilatory functions were observed among subjects in the propolis group. A decrease in serum levels of TNF- $\alpha$, IL-6, IL-8, and intercellular adhesion molecule-1 (ICAM-1) and an increase in serum levels of IL-10 were observed. Serum levels of $\mathrm{PGE}_{2}, \mathrm{PGF}_{2 \alpha}$, and $\mathrm{LTD}_{4}$ were also reduced compared to baseline values. The authors reported that many subjects in the propolis group required fewer doses of their rescue medication, salbutamol, throughout the study period. These findings indicate that propolis aqueous extract as a nutritional supplement may be beneficial in asthma management.

Another clinical trial evaluating the effectiveness of propolis cera tablets to ameliorate asthma symptoms was conducted by Mirsadraee et al. (2020). Subjects with moderate persistent asthma were randomly assigned to receive three propolis cera tablets (each containing $75 \mathrm{mg}$ propolis) or placebo tablets daily for a month. Propolis treatment attenuated asthma symptoms such as cough, dyspnea, wheezing, and nocturnal attacks. Airway hyperresponsiveness, pulmonary function, and asthma control also showed significant improvements. Furthermore, propolis treatment reduced fractional exhaled nitric oxide (FeNO) and sputum eosinophils in the propolis group. At the end of the trial, a reduced frequency of asthma attacks and emergency department visits was recorded among the subjects receiving propolis treatment. Overall, this study suggests the potential therapeutic effects of propolis for asthma.

\section{Atopic Sensitization and Eczema}

A randomized, double-blind, placebo-controlled trial was conducted by Igarashi et al. (2019) to evaluate the effects of Brazilian green propolis extract given as a supplement to lactating women on atopic sensitization and eczema in their offspring (Igarashi et al., 2019). This study demonstrates that lactating women taking Brazilian green propolis did not affect the risk of their offspring in developing atopic sensitization on their first birthday, as indicated by similar serum levels of total IgE as well as antigen-specific IgE (mites, egg white, cow's milk, and wheat) between the placebo and propolis groups. At the same time, the non-specific symptoms (eczema) neither improved nor worsened in the mothers and their offspring. While these findings seem to discourage the use of Brazilian green propolis extract for atopic conditions such as eczema, the authors suggested a few possibilities which could result in the lack of efficacy of propolis. Firstly, the sample size was small due to many dropouts $(n=26)$. Furthermore, we also noticed that no baseline values were taken for serum levels of total $\operatorname{IgE}$ and antigen-specific IgE. Comparison of serum IgE levels should also be made between the baseline and the first birthday of the same infant. Nevertheless, no serious adverse events were reported throughout the study period among the mothers and their offspring, except for one mother who had mild nausea that lasted temporarily, indicating that Brazilian green propolis is safe as a supplement for lactating women.

\section{ACTIVE CONSTITUENTS OF PROPOLIS WITH ANTI-ALLERGIC PROPERTIES}

Looking closely into the studies that reported anti-allergic activities of propolis, not all of them determined the chemical composition and active constituents of the propolis samples (Supplementary Table S1). As the chemical composition of propolis varies according to geographical locations, climates, botanical sources, and bee species (Katekhaye et al., 2019), it is difficult to relate the anti-allergic properties of propolis from different sources when the chemical composition is not known. However, several researchers have attributed the anti-allergic activities of propolis to the presence of flavonoids such as chrysin, kaempferol, galangin, and pinocembrin (Shinmei et al., 2009; Nakamura et al., 2010; Shinmei et al., 2010). These compounds have been demonstrated to have potential therapeutic effects for different allergic diseases in vivo, such as asthma (kaempferol, pinocembrin) (Gong et al., 2012; Gu et al., 2017), atopic dermatitis (chrysin) (Choi et al., 2017) as well as anaphylaxis (galangin) (Kim et al., 2013) (Figure 1).

Among the studies discussed here, Brazilian green propolis is the most common type of propolis that has been investigated for its anti-allergic activities. However, the potential active constituents contributing to these anti-allergic activities remain unknown, except for allergen-induced allergic inflammation in vitro. The active constituents were likely to be artepillin C, baccharin and kaempferide (Tani et al., 2010). Besides that, different sources of Brazilian propolis that have shown anti-allergic activities, such as the standardized Brazilian green propolis extract, EPP-AF ${ }^{\circledR}$ (Piñeros et al., 2020) and Brazilian green propolis from Yamada Bee Company Inc. (Shinmei et al., 2004; Shinmei et al., 2009; Shinmei et al., 2010; Ohkura et al., 2016; Shaha et al., 2018), contain compounds such as caffeic acid, coumaric acid, naringenin, kaempferide, and pinocembrin. The anti-allergic properties of these compounds remain to be fully explored.

As several studies have demonstrated the anti-allergic activities of Brazilian green propolis, it is surprising to note that the major constituent artepillin $\mathrm{C}$ has not been tested in experimental models of allergic diseases, except for an in vitro study by Tani et al. (2010) which evaluated the effects of artepillin C on allergen-induced allergic inflammation (Tani et al., 2010). 
Artepillin $\mathrm{C}$ is the most abundant compound of Brazilian green propolis that differentiates it from the other types of propolis from different regions (Huang et al., 2014). Future studies could be carried out to evaluate the anti-allergic potential of artepillin C. Besides that, caffeic acid phenethyl ester (CAPE) is a natural derivative of caffeic acid that has drawn many researchers' attention due to its potent antioxidant, anti-inflammatory, and anticancer effects (Armutcu et al., 2015). CAPE has also been demonstrated to suppress OVA-induced active systemic anaphylaxis (Park et al., 2008) and asthma (Jung et al., 2008). However, Brazilian green propolis has been claimed to contain no CAPE (Berretta et al., 2017), including the standardized Brazilian green propolis that showed an antiasthmatic effect (Hori et al., 2013; Piñeros et al., 2020). Although it is unclear whether some propolis extracts discussed here (Table 1) contain CAPE, CAPE was found in other sources of Chinese propolis (Chang et al., 2017), Turkish propolis (Özkök et al., 2021), and Egyptian propolis (Abd El Hady and Hegazi, 2002). Whether CAPE contributes to the reported anti-allergic activities of Chinese propolis (Nakamura et al., 2010), Turkish propolis (Yasar et al., 2016), and Egyptian propolis (El-Aidy et al., 2015) remains to be explored in future studies.

\section{POTENTIAL THERAPEUTIC USE OF PROPOLIS IN ALLERGIC DISEASES: PROSPECTS AND CHALLENGES}

Both preclinical and clinical studies have shown that propolis extracts have promising anti-allergic effects against allergic inflammation, asthma, allergic rhinitis, atopic dermatitis, and food allergy, which may be partly attributed to their inhibitory effects on the activation of effector cells such as mast cells and basophils. These findings indicate that propolis may be a potential remedy for allergic diseases. However, there is a lack of clinical trials, especially those evaluating the anti-allergic effects of the active constituents. Also, it should be noted that there are concerns about the increased prevalence of propolis allergy in some countries such as the United States (Shi et al., 2016), Singapore (Kwong and Lim, 2020), and Germany (Hausen, 2005). Notably, Hausen (2005) showed that CAPE is the primary contact allergen in propolis, followed by benzyl caffeate, 3-methyl-2-butenyl caffeate, and geranyl caffeate (Hausen, 2005). Besides that, it has been reported that up to $28.6 \%$ of beekeepers were sensitized to propolis, probably because of their higher exposure to propolis (Oosterhaven et al., 2019). Although it remains debatable whether propolis itself could serve as a sensitizing agent as the chemical composition of propolis varies (Valero Da Silva et al., 2019), it is reasonable to conclude that topical use of propolis may not be favourable for specific allergic individuals.

In this review, all three clinical studies discussed demonstrate that propolis is safe to be consumed as a supplement as no adverse events were reported among the asthmatic patients (Khayyal et al., 2003; Mirsadraee et al., 2020) or lactating women (Igarashi et al., 2019) who consumed propolis in the forms of capsule, tablet or milk product, except for one lactating mother who had mild and transient nausea (Igarashi et al., 2019). Furthermore, an in vivo study by Yasar et al. (2016) showed that oral propolis is more effective than topical (intranasal) propolis as a treatment for allergic rhinitis (Yasar et al., 2016). It is worthwhile to evaluate the potential of propolis as an adjunct therapy for allergic diseases, including allergic rhinitis and atopic dermatitis, in the clinical settings as Khayyal et al. (2003) demonstrated that the addition of propolis into the treatment regime for asthma with oral theophylline significantly improved the conditions of asthmatic patients (Khayyal et al., 2003). However, an allergy test may need to be conducted for individuals who want to use propolis as a CAM to treat allergic conditions and avoid undesirable side effects. Lastly, there are some significant challenges to the commercialization of propolis, including the lack of a standardization method for quality control of propolis from different sources due to its complex chemical composition, the difficulty in obtaining a quality source of propolis, and the declining bee populations (reviewed by Katekhaye et al., 2019). Although propolis is available in the market as a supplement, more studies are needed in the future to facilitate the development of propolis for prophylactic or therapeutic use in allergic diseases.

\section{CONCLUSION}

In conclusion, propolis has promising potential to be further developed for prophylactic or therapeutic use in allergic diseases, such as asthma, allergic rhinitis, and atopic dermatitis, as its therapeutic benefits are well-supported by both preclinical and clinical studies. However, as the chemical composition of propolis varies according to geographical locations, climates, botanical sources, and bee species, future studies should relate the anti-allergic activity of propolis with its chemical composition particularly chrysin, kaempferol, galangin, pinocembrin, CAPE, and artepillin $\mathrm{C}$ to ensure the results reproducibility and to discover novel anti-allergic compounds. Clinical studies are also required to evaluate the effects of these active constituents on allergic diseases. Besides that, it is worthwhile to assess the efficacy of propolis as a supplement or an adjunct therapy to treat allergic rhinitis and atopic dermatitis in clinical settings as such an approach has been proven to be safe and effective for asthmatic patients.

\section{AUTHOR CONTRIBUTIONS}

KYL, NIK, HMO, PYAY, and FI searched for articles and drafted the manuscript. CLT conceived the idea and supervised the study. CLT and JWT reviewed the draft and contributed to critical revision of the draft. All authors approved the final version of the manuscript.

\section{FUNDING}

This project was supported by Universiti Putra Malaysia under Geran Putra Berimpak (UPM/800-3/3/1/GPB/9657600). KYL was a recipient of Universiti Putra Malaysia Graduate Research Assistantship (GRA) and Special Graduate Research Allowance Scheme (SGRA). 


\section{ACKNOWLEDGMENTS}

The authors would like to thank the members of Cell Signalling Laboratory, Faculty of Medicine and Health Sciences, Universiti Putra Malaysia, for providing technical supports for this study.

\section{REFERENCES}

Abd El Hady, F. K., and Hegazi, A. G. (2002). Egyptian Propolis: 2. Chemical Composition, Antiviral and Antimicrobial Activities of East Nile Delta Propolis. Z. Naturforsch C J. Biosci. 57 (3-4), 386-394. doi:10.1515/znc2002-3-431

Akdis, M. (2014). New Treatments for Allergen Immunotherapy. World Allergy Organ. J. 7 (1), 23-25. doi:10.1186/1939-4551-7-23

Anjum, S. I., Ullah, A., Khan, K. A., Attaullah, M., Khan, H., Ali, H., et al. (2019). Composition and Functional Properties of Propolis (Bee Glue): A Review. Saudi J. Biol. Sci. 26 (7), 1695-1703. doi:10.1016/j.sjbs.2018.08.013

Armutcu, F., Akyol, S., Ustunsoy, S., and Turan, F. F. (2015). Therapeutic Potential of Caffeic Acid Phenethyl Ester and its Anti-inflammatory and Immunomodulatory Effects (Review). Exp. Ther. Med. 9 (5), 1582-1588. doi:10.3892/etm.2015.2346

Baiardini, I., Novakova, S., Mihaicuta, S., Oguzulgen, I. K., and Canonica, G. W. (2019). Adherence to Treatment in Allergic Respiratory Diseases. Expert Rev. Respir. Med. 13 (1), 53-62. doi:10.1080/17476348.2019.1554438

Berretta, A. A., Arruda, C., Miguel, F. G., BaptistaNascimento, N., Nascimento, A. P., Marquele-Oliveira, F., et al. (2017). Functional Properties of Brazilian Propolis: From Chemical Composition until the Market. Superfood and Functional Food - an Overview of Their Processing and Utilization. doi:10.5772/65932

Chang, H., Wang, Y., Yin, X., Liu, X., and Xuan, H. (2017). Ethanol Extract of Propolis and its Constituent Caffeic Acid Phenethyl Ester Inhibit Breast Cancer Cells Proliferation in Inflammatory Microenvironment by Inhibiting TLR4 Signal Pathway and Inducing Apoptosis and Autophagy. BMC Complement. Altern. Med. 17 (1). doi:10.1186/S12906-017-1984-9

Choi, J. K., Jang, Y. H., Lee, S., Lee, S. R., Choi, Y. A., Jin, M., et al. (2017). Chrysin Attenuates Atopic Dermatitis by Suppressing Inflammation of Keratinocytes. Food Chem. Toxicol. 110, 142-150. doi:10.1016/j.fct.2017.10.025

De Farias, J. H. C. D., Reis, A. S., Araújo, M. A. R., Araújo, M. J. A. M., Assunção, A. K. M., Farias, J. C., et al. (2014). Effects of Stingless Bee Propolis on Experimental Asthma. Evidence-Based Complement. Altern. Med. 2014. doi:10.1155/2014/951478

El-Aidy, W. K., Ebeid, A. A., Sallam, A. E. R. M., Muhammad, I. E., Abbas, A. T., Kamal, M. A., et al. (2015). Evaluation of Propolis, Honey, and Royal Jelly in Amelioration of Peripheral Blood Leukocytes and Lung Inflammation in Mouse Conalbumin-Induced Asthma Model. Saudi J. Biol. Sci. 22 (6), 780-788. doi:10.1016/j.sjbs.2014.11.005

Gong, J. H., Shin, D., Han, S. Y., Kim, J. L., and Kang, Y. H. (2012). Kaempferol Suppresses Eosinophil Infiltration and Airway Inflammation in Airway Epithelial Cells and in Mice with Allergic Asthma. J. Nutr. 142 (1), 47-56. doi:10.3945/jn.111.150748

Gu, X., Zhang, Q., Du, Q., Shen, H., and Zhu, Z. (2017). Pinocembrin Attenuates Allergic Airway Inflammation via Inhibition of NF-Kb Pathway in Mice. Int. Immunopharmacology 53 (May), 90-95. doi:10.1016/j.intimp.2017.10.005

Hausen, B. M. (2005). Evaluation of the Main Contact Allergens in Propolis (1995 to 2005). Dermatitis 16 (3), 127-129. doi:10.1097/01206501-200509000-00007

Hori, J. I., Zamboni, D. S., Carrão, D. B., Goldman, G. H., and Berretta, A. A. (2013). The Inhibition of Inflammasome by Brazilian Propolis (EPP-AF). Evidence-Based Complement. Altern. Med. 2013. doi:10.1155/2013/418508

Huang, S., Zhang, C. P., Wang, K., Li, G. Q., and Hu, F. L. (2014). Recent Advances in the Chemical Composition of Propolis. Molecules 19 (12), 19610-19632. doi:10.3390/molecules191219610

Igarashi, G., Segawa, T., Akiyama, N., Nishino, T., Ito, T., Tachimoto, H., et al. (2019). Efficacy of Brazilian Propolis Supplementation for Japanese Lactating Women for Atopic Sensitization and Non-specific Symptoms in Their Offspring: A Randomized, Double-Blind, Placebo-Controlled Trial. Evidence-Based Complement. Altern. Med. 2019. doi:10.1155/2019/8647205

\section{SUPPLEMENTARY MATERIAL}

The Supplementary Material for this article can be found online at: https://www.frontiersin.org/articles/10.3389/fphar.2021.785371/ full\#supplementary-material

Jung, W. K., Lee, D. Y., Choi, Y. H., Yea, S. S., Choi, I., Park, S. G., et al. (2008). Caffeic Acid Phenethyl Ester Attenuates Allergic Airway Inflammation and Hyperresponsiveness in Murine Model of Ovalbumin-Induced Asthma. Life Sci. 82 (13-14), 797-805. doi:10.1016/j.lfs.2008.01.014

Kashiwakura, J. I, Yoshihara, M., Saitoh, K., Kagohashi, K., Sasaki, Y., Kobayashi, F., et al. (2021). Propolis Suppresses Cytokine Production in Activated Basophils and Basophil-Mediated Skin and Intestinal Allergic Inflammation in Mice. Allergol. Int. 70 (3), 360-367. doi:10.1016/ j.alit.2020.11.005

Katekhaye, S., Fearnley, H., Fearnley, J., and Paradkar, A. (2019). Gaps in Propolis Research: Challenges Posed to Commercialization and the Need for an Holistic Approach. J. Apicultural Res. 58 (4), 604-616. doi:10.1080/ 00218839.2019.1614273

Khayyal, M. T., El-Ghazaly, M. A., El-Khatib, A. S., Hatem, A. M., De Vries, P. J. F., El-Shafei, S., et al. (2003). A Clinical Pharmacological Study of the Potential Beneficial Effects of a Propolis Food Product as an Adjuvant in Asthmatic Patients. Fundam. Clin. Pharmacol. 17 (1), 93-102. doi:10.1046/j.14728206.2003.00117.x

Khosravi, A. R., Alheidary, S., Nikaein, D., and Asghari, N. (2018). Aspergillus fumigatus Conidia Stimulate Lung Epithelial Cells (TC-1 JHU-1) to Produce IL-12, IFN $\gamma$, IL-13 and IL-17 Cytokines: Modulatory Effect of Propolis Extract. J. de Mycologie Medicale 28 (4), 594-598. doi:10.1016/ j.mycmed.2018.09.006

Kim, H. H., Bae, Y., and Kim, S. H. (2013). Galangin Attenuates Mast CellMediated Allergic Inflammation. Food Chem. Toxicol. 57, 209-216. doi:10.1016/j.fct.2013.03.015

Kruse, R. L., and Vanijcharoenkarn, K. (2018). Drug Repurposing to Treat Asthma and Allergic Disorders: Progress and Prospects. Allergy Eur. J. Allergy Clin. Immunol. 73 (2), 313-322. doi:10.1111/all.13305

Kun, L., and Li, L. (2016). Therapeutic Strategies towards Allergic Diseases. Int. J. Allergy Medications 2 (1), 1-6. doi:10.23937/2572-3308.1510011

Kuropatnicki, A. K., Szliszka, E., and Krol, W. (2013). Historical Aspects of Propolis Research in Modern Times. Evidence-Based Complement. Altern. Med. 2013. doi:10.1155/2013/964149

Kwong, H. L., and Lim, S. P. R. (2020). Prevalence of Propolis Allergy in Singapore. JAAD Int. 1 (1), 39-41. doi:10.1016/j.jdin.2020.04.001

Mirsadraee, M., Azmoon, B., Ghaffari, S., Abdolsamadi, A., and Khazdair, M. R. (2020). Effect of Propolis on Moderate Persistent Asthma: A Phase Two Randomized, Double-Blind, Controlled Clinical Trial. Avicenna J. Phytomedicine 11 (1), 22-31. doi:10.22038/AJP.2020.15777

Nakamura, R., Nakamura, R., Watanabe, K., Oka, K., Ohta, S., Mishima, S., et al. (2010). Effects of Propolis from Different Areas on Mast Cell Degranulation and Identification of the Effective Components in Propolis. Int. Immunopharmacology 10 (9), 1107-1112. doi:10.1016/ j.intimp.2010.06.013

Ohkura, N., Oishi, K., Kihara-Negishi, F., Atsumi, G. I., and Tatefuji, T. (2016). Effects of a Diet Containing Brazilian Propolis on Lipopolysaccharide-Induced Increases in Plasma Plasminogen Activator Inhibitor-1 Levels in Mice. J. Intercultural Ethnopharmacology 5 (4), 439-443. doi:10.5455/ jice.20160814112735

Oosterhaven, J. A. F., Verbist, J., and Schuttelaar, M.-L. A. (2019). Hand Eczema Among Dutch Beekeepers - a Cross-Sectional Study. JDDG: J. Der Deutschen Dermatologischen Gesellschaft 17 (2), 158-166. doi:10.1111/ DDG.13754

Özkök, A., Keskin, M., Tanuğur Samanc1, A. E., Yorulmaz Önder, E., and Takma, Ç. (2021). Determination of Antioxidant Activity and Phenolic Compounds for Basic Standardization of Turkish Propolis. Appl. Biol. Chem. 64 (1). doi:10.1186/s13765-021-00608-3

Park, S. G., Lee, D. Y., Seo, S. K., Lee, S. W., Kim, S. K., Jung, W. K., et al. (2008). Evaluation of Anti-allergic Properties of Caffeic Acid Phenethyl Ester in a 
Murine Model of Systemic Anaphylaxis. Toxicol. Appl. Pharmacol. 226 (1), 22-29. doi:10.1016/j.taap.2007.08.003

Pasupuleti, V. R., Sammugam, L., Ramesh, N., and Gan, S. H. (2017). Honey, Propolis, and Royal Jelly: A Comprehensive Review of Their Biological Actions and Health Benefits. Oxidative Med. Cell Longevity 2017. doi:10.1155/2017/ 1259510

Pawankar, R. (2014). Allergic Diseases and Asthma: A Global Public Health Concern and a Call to Action. World Allergy Organ. J. 7 (1), 1-3. doi:10.1186/1939-4551-7-12

Piñeros, A. R., de Lima, M. H. F., Rodrigues, T., Gembre, A. F., Bertolini, T. B., Fonseca, M. D., et al. (2020). Green Propolis Increases Myeloid Suppressor Cells and CD4+Foxp3+ Cells and Reduces Th2 Inflammation in the Lungs after Allergen Exposure. J. Ethnopharmacology 252 (July), 112496. doi:10.1016/ j.jep. 2019.112496

Shaha, A., Mizuguchi, H., Kitamura, Y., Fujino, H., Yabumoto, M., Takeda, N., et al. (2018). Effect of Royal Jelly and Brazilian Green Propolis on the Signaling for Histamine H1 Receptor and Interleukin-9 Gene Expressions Responsible for the Pathogenesis of the Allergic Rhinitis. Biol. Pharm. Bull. 41 (9), 1440-1447. doi:10.1248/BPB.B18-00325

Shi, Y., Nedorost, S., Scheman, L., and Scheman, A. (2016). Propolis, Colophony, and Fragrance Cross-Reactivity and Allergic Contact Dermatitis. Dermatitis : Contact Atopic, Occup. Drug 27 (3), 123. doi:10.1097/DER.0000000000000186

Shinmei, Y., Hossen, M. A., Okihara, K., Sugimoto, H., Yamada, H., and Kamei, C. (2004). Effect of Brazilian Propolis on Scratching Behaviour Induced by Compound $48 / 80$ and Histamine in Mice. Int. Immunopharmacology 4 (10-11), 1431-1436. doi:10.1016/j.intimp.2004.06.007

Shinmei, Y., Kagawa, Y., Yano, H., Hossen, M. A., and Kamei, C. (2010). Effect of Topical Application of Brazilian Propolis on Scratching Behaviour Induced by Compound 48/80 in Mice. Immunopharmacology and Immunotoxicology 32 (2), 327-332. doi:10.3109/08923970903349281

Shinmei, Y., Yano, H., Kagawa, Y., Izawa, K., Akagi, M., Inoue, T., et al. (2009). Effect of Brazilian Propolis on Sneezing and Nasal Rubbing in Experimental Allergic Rhinitis of Mice. Immunopharmacology and Immunotoxicology 31 (4), 688-693. doi:10.3109/08923970903078443

Stone, K. D., Prussin, C., and Metcalfe, D. D. (2010). IgE, Mast Cells, Basophils, and Eosinophils. J. Allergy Clin. Immunol. 125 (2 Suppl. 2), S73. doi:10.1016/ J.JACI.2009.11.017
Sy, L. B., Wu, Y. L., Chiang, B. L., Wang, Y. H., and Wu, W. M. (2006). Propolis Extracts Exhibit an Immunoregulatory Activity in an OVA-Sensitized Airway Inflammatory Animal Model. Int. Immunopharmacology 6 (7), 1053-1060. doi:10.1016/j.intimp.2006.01.015

Tani, H., Hasumi, K., Tatefuji, T., Hashimoto, K., Koshino, H., and Takahashi, S. (2010). Inhibitory Activity of Brazilian green Propolis Components and Their Derivatives on the Release of Cys-Leukotrienes. Bioorg. Med. Chem. 18 (1), 151-157. doi:10.1016/j.bmc.2009.11.007

Valero Da Silva, M., Gomes De Moura, N., Motoyama, A. B., and Ferreira, V. M. (2019). A Review of the Potential Therapeutic and Cosmetic Use of Propolis in Topical Formulations ARTICLE INFO. J. Appl. Pharm. Sci. 0 (00), 1-011. doi:10.7324/JAPS.2018.8801

Yasar, M., Savranlar, Y., Karaman, H., Sagit, M., Silici, S., and Ozcan, I. (2016). Effects of Propolis in an Experimental Rat Model of Allergic Rhinitis. Am. J. Otolaryngology-Head Neck Med. Surg. 37 (4), 287-293. doi:10.1016/ j.amjoto.2016.03.007

Zulhendri, F., Chandrasekaran, K., Kowacz, M., Ravalia, M., Kripal, K., Fearnley, J., et al. (2021). Antiviral, Antibacterial, Antifungal, and Antiparasitic Properties of Propolis: A Review. Foods 10 (6). doi:10.3390/foods10061360

Conflict of Interest: The authors declare that the research was conducted in the absence of any commercial or financial relationships that could be construed as a potential conflict of interest.

Publisher's Note: All claims expressed in this article are solely those of the authors and do not necessarily represent those of their affiliated organizations, or those of the publisher, the editors, and the reviewers. Any product that may be evaluated in this article, or claim that may be made by its manufacturer, is not guaranteed or endorsed by the publisher.

Copyright $\odot 2022$ Liew, Kamise, Ong, Aw Yong, Islam, Tan and Tham. This is an open-access article distributed under the terms of the Creative Commons Attribution License (CC BY). The use, distribution or reproduction in other forums is permitted, provided the original author(s) and the copyright owner(s) are credited and that the original publication in this journal is cited, in accordance with accepted academic practice. No use, distribution or reproduction is permitted which does not comply with these terms. 